\title{
Potential of Methocinnamox to Treat Opioid Misuse
}

\author{
Colleen G. Jordan, MBS'*, Amy L. Kennalley, MBS', Tenzing Dolma, MBS', Kaitlyn M. Nemes, MBS', Alivia L. \\ Roberts, MBS ${ }^{1}$, Brian J. Piper, PhD ${ }^{1,2}$ \\ ${ }^{1}$ Department of Medical Education, Geisinger Commonwealth School of Medicine, Scranton, PA 18509, USA \\ ${ }^{2}$ Center for Pharmacy Innovation and Outcomes, Forty Fort, PA 18704, USA \\ *Correspondence: Colleen G. Jordan, MBS, ORCID 0000-0002-1434-6956 cjordan02@som.geisinger.edu, \\ colleenjordan1@creighton.edu
}

\begin{abstract}
The opioid epidemic is an ongoing public health crisis, and the United States health system is overwhelmed with increasing numbers of opioid-related overdoses. Methocinnamox (MCAM) is a novel mu-opioid receptor antagonist with an extended duration of action and potential to reduce the burden of the opioid epidemic through overdose rescue and could treat opioid use disorder (OUD) long-term. We compared the efficacy and effects of MCAM to the current treatments available to treat OUD including naloxone, naltrexone, methadone, and buprenorphine which have their own limitations including short duration of action, patient non-compliance, and diversion. A literature review was conducted using PubMed and Google Scholar databases covering the history of the opioid epidemic, pain receptors, current OUD treatments and the novel drug MCAM. MCAM could potentially be used as both a rescue and longterm treatment for opioid misuse. This is due to its pseudo-irreversible antagonism of the mu opioid receptor, abnormally long duration of action of nearly two weeks, and the possibility of using kappa or delta opioid receptor agonists for pain management during OUD treatment. MCAM's novel pharmacokinetic and pharmacodynamic properties open a new avenue for treating the opioid crisis.
\end{abstract}

Keywords: methocinnamox; opioid; naloxone; naltrexone; methadone; buprenorphine; overdose; treatment; receptors; addiction

\section{Introduction}

Over one-million Americans have died from overdoses during the opioid epidemic. ${ }^{1}$ Opioid addiction and misuse remains a prevalent issue in the United States (US) leading to millions of deaths. ${ }^{2}$ Opioids were originally discovered from poppy plants and were used to reduce pain sensation ranging from acute to severe, but they have become more accessible for recreational use outside of pain relief therapy. ${ }^{3,4}$ The intended use of opioids was for the reduction of pain sensation by agonizing the opioid receptors located in the central nervous system (CNS). ${ }^{5}$ There are three major opioid receptor types, $\mathrm{mu}(\mu)$, delta $(\delta)$, and kappa $(\kappa)$, but the mu-receptor is the main target of exogenous opioids ${ }^{5,6}$. In the past, many people turned to opioids to relieve daily suffering from chronic pain, and the drugs easily became addictive and created dependence. ${ }^{2}$ The ubiquitous use of opioids and the addiction to these drugs in the US have exacerbated the strain on resources in hospitals, emergency rooms, and on first responders as they try to save lives with the limited resources currently available. ${ }^{2}$ Naloxone is the only drug available to treat opioid overdose to be approved by the US Food and Drug Administration (FDA) in the last 50 years, and the opioid users are younger and experimenting with synthetic opioids beyond pain relief. ${ }^{7,8}$ Naloxone is a competitive mu opioid antagonist with a high affinity for the mu-receptor used to reverse respiratory and CNS depression in those enduring an opioid overdose.9,10 Naloxone does not help decrease future use of opioids, and the use of 
synthetic opioids will require higher doses of naloxone which could increase adverse effects such as tachycardia and hypertension. ${ }^{11,12}$ Naloxone is also currently misused at "Narcan parties," where attendees intentionally overdose knowing they will be rescued by naloxone. ${ }^{13}$ Naltrexone has extendedrelease formulas intended to reduce relapse and promote compliance, yet patient noncompliance and retention continue to be limiting factors. ${ }^{14}$ Methadone is commonly used to treat opioid addiction as a replacement for illicit opiates but is itself an addictive substance that can lead to withdrawal if dosage is not closely monitored by a licensed professional. ${ }^{15}$ Buprenorphine is currently used to treat OUD and while it reduces illicit drug use, it is equal to or even less effective than methadone in patient retention in treatment. ${ }^{15}$ Additionally, buprenorphine is sold on the blackmarket for those attempting to treat opioid dependency on their own and was involved in more drug arrests than methadone. ${ }^{16,17}$ Methadone and buprenorphine are substitution treatments with substantial reduction of opioid deaths during treatment but immediately following release from treatment mortality risk notably returns to increased levels. ${ }^{18}$ For these reasons, ${ }^{1,2}$ there is a dire need for a new opioid misuse intervention. ${ }^{19}$

Methocinnamox (MCAM) is a novel drug candidate that is a pseudo-irreversible antagonist for the mu opioid receptor (MOR), thereby preventing other opioid agonists from binding for a two-week period ${ }^{19-21}$. Due to the long-lasting effect of MCAM, it can be a safer and more effective alternative medication for the misuse of opioids. ${ }^{22,23}$ MCAM has the potential to change the course of opioid misuse and help prevent relapse after administration. ${ }^{24,25}$ This brief review will explore how MCAM's unique function could be useful in reducing the burden of the opioid crisis.

\section{Methods}

A literature review was conducted using PubMed and Google Scholar databases utilizing the following key terms: methocinnamox, MCAM, naloxone, naltrexone, buprenorphine, buprenorphine-naloxone, methadone, opioid overdose, opioid crisis, opioid abuse, mu-receptor, kappa-receptor, delta-receptor, inverse agonist, and naloxone and placebo. These terms and pharmacotherapies were included due to their relevance to the opioid epidemic, opioid overdose, and MCAM. Chemical structure was constructed with ChemDraw version 19.0.0. No date range or journal exclusion criteria were applied.

\section{Discussion}

\subsection{Opioid Epidemic}

In the 1800s, opiates were widely marketed as a safe and effective form of pain alleviation. ${ }^{26}$ Consequently, the absence of federal regulation on frequent opioid prescription and use drew widespread concern, which eventually led to the enactment of the 1914 Harrison Narcotic Control Act. ${ }^{27}$ While this prompted nationwide stigmatization of opioid use for non-cancer chronic pain management, it was later followed by a drastic shift in 1995 in public attitude that advocated for the recognition of pain as a 'fifth vital sign'. ${ }^{28}$ As a result, several entities such as the Institute of Medicine, the Federation of State Medical Boards, and the Drug Enforcement Agency, pushed for fewer regulations over opioid prescriptions, thereby encouraging healthcare providers to provide adequate pain relief for patients. Additionally, the FDA approved an extended-release oxycodone formulation in 1995 as a safer opioid alternative to the fast-release version because of its slow and sustained release of medication. ${ }^{29}$ Pressure by pharmaceutical companies, patients, and federal funding requirements further contributed to the 
overaggressive prescription of opioid analgesics that ultimately led to the opioid epidemic in the US. ${ }^{30,31}$ The Centers for Disease Control reported that in 2016, more than 42,000 Americans died from an opioid overdose, marking a $27 \%$ increase from the previous year. ${ }^{32}$ In 2017 , the rate increased by $45.2 \%$, indicating the increased prevalence of opioid misuse. ${ }^{33}$ More than 11.5 million Americans misused opioids and roughly 2.1 million were formally diagnosed with an OUD. ${ }^{34}$ Later that year, the US Department of Health and Human Services declared the opioid epidemic a public health emergency. Despite concerted efforts by medical practitioners to reduce opioid prescriptions and increased availability of buprenorphine, methadone, and naloxone, ${ }^{35-37}$ opioid overdose continues to rise with one-hundred thousand annually, ${ }^{38}$ with the illegal manufacturing of fentanyl and its analogs as the leading cause. ${ }^{39}$ This can be attributed to fentanyl's high potency, with a strength that is 30-50 times greater than that of heroin, its rapid onset of action, long duration of desired effect, and low production costs. While the rate of heroin-related overdose deaths has started to stabilize, from 2013-2016 synthetic opioid related deaths, such as those caused by fentanyl and its analogs, increased by $88 \% .30,40$

Public health experts agree that tackling the opioid epidemic will require interdisciplinary collaboration between medical providers, social service agencies, federal regulation, and community support. ${ }^{8,41,42}$ The lingering effects of the epidemic are rampant in low-income communities, predominantly African American and Hispanic communities, and are currently exacerbated by COVID-19's social and health impacts. ${ }^{43,44}$ Potential proposed solutions include increasing harmreduction programs, educating medical providers on safe opioid prescribing, eliminating stigma around OUDs, as well as finding safer alternatives to pain management. ${ }^{3,42,45}$ Current OUD therapeutics include methadone, buprenorphine, naloxone, and extended-release naltrexone, all of which function by reducing opioid withdrawal symptoms and cravings. ${ }^{5,46}$ However, drug addiction is generally recognized as a complex biopsychosocial condition. These medications can only successfully resolve the opioid crisis by working in tandem with public health efforts that include both prevention and harm-reduction approaches. ${ }^{47}$ MCAM presents potential for a new avenue of OUD treatment.

\subsection{Pain Receptors}

MCAM is a long lasting, pseudo-irreversible (non-covalent binding), potent, MOR antagonist which reversibly binds kappa opioid receptors (KOR) and delta opioid receptors (DOR) that has no known interaction with other nociceptors. Thus, kappa and delta agonists could be provided concomitantly for pain relief during treatment for OUD. ${ }^{20,22-24,48,49}$ This unique pharmacodynamic mechanism of MCAM contributes to its long-lasting effects. The need for new MORs to induce the euphoric and depressive effects of opioid receptor agonists as receptor turnover is what limits the DOA. ${ }^{19,24}$ This is crucial because MOR agonists can not only induce the $G$ protein-coupled receptor (GPCR) pathway, but can also induce $\beta$-arrestin activation, leading to adverse effects such as respiratory depression. ${ }^{50,51}$ The opioid receptors: MOR, KOR, and DOR, belong to the largest membrane receptor family called the trimeric GPCR superfamily, with opioids activating the inhibitory (Gi) signaling pathway to initiate analgesic functions. ${ }^{52-55}$ The GPCRs are known for their trimeric subunits consisting of alpha $(\mathrm{G} \alpha)$, beta $(\mathrm{G} \beta)$, and gamma $(G \gamma){ }^{56}$ After the opioid agonist (endogenous or exogenous) binds, a signal stimulates $\mathrm{G} \alpha$ to migrate and suppress adenylate cyclase activity, thereby reducing cyclic AMP production. ${ }^{56}$ The $G \beta \gamma$ acts as a modulator for the signaling pathway, resulting in reduced neurotransmitter release and membrane hyperpolarization. ${ }^{56}$

Since GPCRs are so widespread, these are the target for $50 \%$ of marketed pharmacological 
therapeutics, revolving around the common aminoterminal peptide sequence, Tyr-Gly-Gly-Phe, which is referred to as the "opioid motif" as it directly interacts with the opioid receptor ${ }^{57}$. The MOR agonists include oxycodone, fentanyl, heroin, morphine, and methadone. Buprenorphine is a partial MOR agonist and KOR antagonist. ${ }^{58,59} \mathrm{MOR}$ antagonists include naloxone, naltrexone, and MCAM. It is believed the activation of KORs antagonizes MOR mediated analgesia; activation of the KOR hyperpolarizes neurons that are active indirectly by the MOR.7 Pain is multidimensional and dependent on subjective thresholds. Chronic pain, which may be concurrent with anxiety, may be associated with neuroplastic changes in the amygdala, which may heighten the emotional and affective consequences of pain.60,61 Analgesics are highly effective in most cases against acute pain, but the desired effects mediated by the opioid receptor family may lead to craving, addiction, or dependence as a result of neurological changes. ${ }^{62-65}$ Repetitive opioid use will thus increase the threshold for analgesic effects secondary to compensatory upregulation of vesicular calcium content while developing opioid tolerance and may decrease one's quality of life. ${ }^{53,66,67}$

\subsection{Current OUD Treatments}

The current pharmacological treatments for opioid overdose and misuse are administration of methadone, buprenorphine, naloxone, and naltrexone. $9,10,12,68-70$ Methadone and buprenorphine are opioid agonists which may prevent withdrawal symptoms in those recovering from OUD, but pose risk for opioid overdose particularly when combined with other substances.68,71,72 However, naltrexone and naloxone are opioid antagonists, the latter being the only emergency rescue for opioid overdose and opioid induced respiratory symptoms..$^{10,73}$ Naltrexone is used to treat OUD and opioid dependency, usually post-opioid cessation, whereas naloxone can be used concomitantly with prescribed opioids such as buprenorphine. ${ }^{68-70,74}$ Other pharmacological uses have been identified for naloxone and naltrexone such as treatment for alcohol dependence, and possible treatments for internet sex addiction, and Hailey-Hailey disease, but studies show these medications are not effective for smoking cessation. ${ }^{75-78}$

Administration of methadone or buprenorphine significantly reduced opioid-related deaths caused by nonfatal opioid overdose over a 12-month follow-up period by $59 \%$ and $38 \%$, respectively. ${ }^{79}$ The abrupt discontinuation of opioids does not show great success rates and may result in relapse. ${ }^{8,68}$ Use of these drugs in conjunction with psychosocial therapy are the best for treatment success in those with OUD. $8,68,70$ While both methadone and buprenorphine are synthetic derivatives of opiates and used in medication assisted treatment (MAT) of OUD, they possess different mechanisms of action and adverse drug reactions (ADRs). Methadone is a long-acting full agonist that binds the MOR, preventing withdrawal symptoms such as nausea and vomiting for at least 24 hours, while conferring analgesia and reducing opioid cravings. ${ }^{80,81}$ Dextromethadone is an NMDA glutamate receptor antagonist. Conversely, buprenorphine is a partial agonist at the MOR, making it less potent than methadone with decreased ADRs. ${ }^{81,82}$ Buprenorphine and its metabolite norbuprenorphine also bind to KOR as an antagonist and DOR as an agonist. 58,82 Methadone has restricted availability in the US and requires daily dosing raising the issue of patient compliance; close monitoring of dosing for detoxification by a practitioner for each individual is an additional healthcare burden. ${ }^{83}$ Buprenorphine is less effective for patient retention than methadone, even at high doses. ${ }^{15}$ Buprenorphine's purported 'ceiling effect' reduces the risk of misuse or overdose by preventing the increase of opioid effects, or euphoria, beyond a designated threshold. ${ }^{81}$ However, buprenorphine may precipitate withdrawal, a condition that occurs without an adequate detoxification period from opioid drugs, due to its high affinity for the MOR. ${ }^{81,82}$ The 
combination of buprenorphine with benzodiazepines causes respiratory depression. ${ }^{81,82}$

An additional drug that is also used in MAT programs is naloxone, which is often paired with buprenorphine in an oral tablet form to prevent strong withdrawal symptoms and block the euphoric effects induced by other opioids. ${ }^{69}$ The mechanistic action of naloxone is by competitive binding to the MOR as a high affinity antagonist, and some researchers suggest it acts as an inverse agonist. 10,84 Administration of naloxone intravenously, intramuscularly, subcutaneously, intranasally, and even inhalation through endotracheal tube for intubated patients during an opioid overdose, competitively binds the opioid receptors to reverse respiratory and CNS depression. ${ }^{85}$ The time to decrease fentanyl occupancy at the receptor after $2 \mathrm{mg}$ intramuscular naloxone administration was three minutes, after 25 $\mathrm{ng} / \mathrm{ml}$ and ten minutes after $50 \mathrm{ng} / \mathrm{ml}$, but there is an increased dose requirement of naloxone due to larger doses of self-administered opioids. ${ }^{12}$ After a $13 \mu \mathrm{g} / \mathrm{kg}$ dose of naloxone, $50 \%$ of the receptors in the brain were occupied, but due to the rapid association and successive dissociation of naloxone from the receptors, toxicity reversal may be insufficient and the patient may experience renarcotization requiring subsequent doses.12,85,86 Although regarded as exceedingly safe, ADRs for naloxone can include tachycardia, hypertension, gastrointestinal upset, hyperthermia, cravings, nausea, vomiting, and rarely severe cardiovascular events. ${ }^{9,12,85}$ Naloxone also blocks the descending pain control system, thus diminishing the placebo pathway for pain perception by interfering with the coupling between the rostral anterior cingulate cortex and the periaqueductal gray area structures in the brain. ${ }^{87,88}$ Though not the first-line treatment for opioid overdose, as it is not as efficacious as naloxone, naltrexone is used to reduce opioid use in those with OUD. 70,73

Naltrexone is commonly characterized as an opioid receptor antagonist, although some suggest an inverse agonist function based on its intracellular signaling properties, that is prescribed to reduce opioid use in those attempting to practice abstinence from opioids but suffer from OUD. ${ }^{70,73}$ Interventions for opioid misuse involving naltrexone, rather than receptor agonists like buprenorphine, have been successful when paired with behavior intervention and are a promising alternative treatment for opioid misuse in pregnant women. 89,90 For opioid dependent pregnancies, naltrexone had reduced opioid misuse in mothers and significantly decreased neonatal abstinence syndrome in infants when compared to buprenorphine. ${ }^{89}$ In contrast to naloxone's associated acute withdrawal symptoms, naltrexone reduces symptoms of withdrawal for patients and even lowers the risk for overdose with the use of buprenorphine as an OUD treatment with no significant ADRs. ${ }^{74}$ While also having a considerable safety profile like naloxone, the potential side effects of naltrexone include mild to moderate injection site reaction, nausea, and gastrointestinal upset. ${ }^{11}$ See Table 1 for a summary comparison of drug treatments. With the intervention's limitations outlined above, MCAM may prove beneficial as a treatment to combat the opioid crisis. 
Table 1. Comparison of opioid use disorder and opioid overdose treatment drugs. Table includes naloxone ${ }^{104,105}$, naltrexone ${ }^{106,107}$, methadone $\mathrm{e}^{108,109}$, buprenorphine $\mathrm{e}^{110,111}$ and methocinnamox (MCAM) $19,24,96,98,99,101$.

\begin{tabular}{|c|c|c|c|c|c|}
\hline $\begin{array}{l}\text { Treatment } \\
\text { Drug }\end{array}$ & $\begin{array}{c}\text { Method of } \\
\text { Administration }\end{array}$ & $\begin{array}{l}\text { Mechanism of } \\
\text { Action }\end{array}$ & $\begin{array}{c}\text { Onset and } \\
\text { Duration of } \\
\text { Action } \\
\end{array}$ & Strengths & Limitations \\
\hline naloxone & $\begin{array}{l}\text { Intravenous } \\
\text { Intramuscular } \\
\text { Subcutaneous } \\
\text { Intranasal } \\
\text { Inhalation }\end{array}$ & $\begin{array}{c}\text { Reversible } \\
\text { MOR, KOR, } \\
\text { DOR } \\
\text { competitive } \\
\text { antagonist }\end{array}$ & $\begin{array}{l}\text { Rapid onset } \\
\text { or } 1-5 \\
\text { minutes } \\
1-2 \text { hours }\end{array}$ & $\begin{array}{l}\text { Rescue from } \\
\text { overdose, wide } \\
\text { therapeutic window }\end{array}$ & $\begin{array}{l}\text { Short DOA, community } \\
\text { misuse, risk of } \\
\text { renarcotization, } \\
\text { precipitates withdrawal, } \\
\text { drug-drug interactions, } \\
\text { surmountable }\end{array}$ \\
\hline naltrexone & $\begin{array}{l}\text { Intravenous } \\
\text { Intramuscular } \\
\text { Subcutaneous }{ }^{1} \\
\quad \text { Oral }\end{array}$ & $\begin{array}{c}\text { Reversible } \\
\text { MOR, KOR, } \\
\text { DOR } \\
\text { competitive } \\
\text { antagonist } \\
\end{array}$ & $\begin{array}{l}15 \text { - } 30 \\
\text { minutes } \\
>72 \text { hours }\end{array}$ & $\begin{array}{c}\text { Use during } \\
\text { pregnancy, } \\
\text { extended-release } \\
\text { formula }\end{array}$ & $\begin{array}{c}\text { May precipitate } \\
\text { withdrawal, patient } \\
\text { noncompliance, drug-drug } \\
\text { interactions }\end{array}$ \\
\hline methadone & $\begin{array}{c}\text { Intravenous } \\
\text { Intramuscular } \\
\text { Subcutaneous } \\
\text { Oral }\end{array}$ & $\begin{array}{l}\text { MOR, DOR } \\
\text { agonist, NMDA } \\
\text { antagonist }\end{array}$ & $\begin{array}{l}\text { 4-8 hours, } \\
\text { single dose; } \\
\text { 22-24 hours, } \\
\text { continuous } \\
\text { dosing }\end{array}$ & $\begin{array}{c}\text { Prevents } \\
\text { withdrawal, reduces } \\
\text { opioid cravings, } \\
\text { pain relief }\end{array}$ & $\begin{array}{l}\text { Patient noncompliance, } \\
\text { dependence, misuse and } \\
\text { diversion, restricted } \\
\text { availability in US, close } \\
\text { monitoring of dosage, } \\
\text { many drug-drug } \\
\text { interactions, ADRs } \\
\end{array}$ \\
\hline buprenorphine & $\begin{array}{c}\text { Intravenous } \\
\text { Intramuscular } \\
\text { Subcutaneous } \\
\text { Oral } \\
\text { Buccal } \\
\text { Sublingual } \\
\text { Transdermal }\end{array}$ & $\begin{array}{c}\text { Partial MOR } \\
\text { agonist, KOR, } \\
\text { DOR } \\
\text { competitive } \\
\text { antagonist }\end{array}$ & $\begin{array}{c}\text { 10-30 } \\
\text { minutes } \\
\text { 2-24 hours }\end{array}$ & $\begin{array}{c}\text { Prevents } \\
\text { withdrawal, use } \\
\text { during pregnancy, } \\
\text { prevents euphoria } \\
\text { and overdose } \\
\text { symptoms }\end{array}$ & $\begin{array}{l}\text { Less potent than } \\
\text { methadone, patient } \\
\text { retention inferior to } \\
\text { methadone, may } \\
\text { precipitate withdrawal, } \\
\text { drug-drug interactions, } \\
\text { ADRs }\end{array}$ \\
\hline MCAM & $\begin{array}{l}\text { Intravenous } \\
\text { Subcutaneous }\end{array}$ & $\begin{array}{c}\text { Pseudo- } \\
\text { irreversible } \\
\text { MOR, not } \\
\text { competitive } \\
\text { antagonist }^{2}, \\
\text { reversible KOR, } \\
\text { DOR } \\
\text { competitive } \\
\text { antagonism } \\
\end{array}$ & $\begin{array}{c}\begin{array}{c}15-45 \\
\text { minutes }\end{array} \\
5 \text { days to } 2 \\
\text { weeks }\end{array}$ & $\begin{array}{c}\text { Long DOA, not } \\
\text { surmountable, } \\
\text { prevents } \\
\text { renarcotization, } \\
\text { lacks notable drug- } \\
\text { drug interactions, } \\
\text { antinociceptive } \\
\text { concomitant } \\
\text { treatment possible } \\
\end{array}$ & $\begin{array}{l}\text { Precipitates withdrawal, } \\
\text { not yet tested in humans }\end{array}$ \\
\hline
\end{tabular}

${ }^{1}$ Subcutaneous formula is a pellet implant

${ }^{2}$ MOA incompletely understood

\subsection{Methocinnamox}

MCAM, shown in Figure 1, was first mentioned in a publication in 2000 by researchers from the University of Michigan Medical School and the University of Bristol, but was initially discarded because it was believed to be useful only for MOR research. 892 However, it is currently being studied for its promise in the opioid crisis as a long-term OUD treatment. ${ }^{93,94}$ In animal models, a single 
subcutaneous dose of MCAM rescues a subject from acute opioid overdose and prevents subsequent overdose for up to two weeks with minimal adverse effects. $21,22,92,95,96$ Currently, the only known possible adverse effect for MCAM in non-dependent individuals was hyperventilation upon rescue. ${ }^{96}$ Interestingly, one study noted a slightly increased response to food (a non-drug alternative) several days following a single injection. ${ }^{22}$ Some studies have shown no statistically significant adverse effects nor potential ADRs with benzodiazepines and alcohol. ${ }^{19,22,97}$ MCAM has not been shown to cause a decrease in response to food or alter heart rate, blood pressure, body temperature, or social and physical activity and no indication of developing tolerance nor physical dependence. ${ }^{19,22}$ MCAM is currently the most potent and selective MOR antagonist and shows no agonistic effects, even at high concentrations, with the longest duration and highest potency when injected subcutaneously over other methods of administration. ${ }^{20,96}$

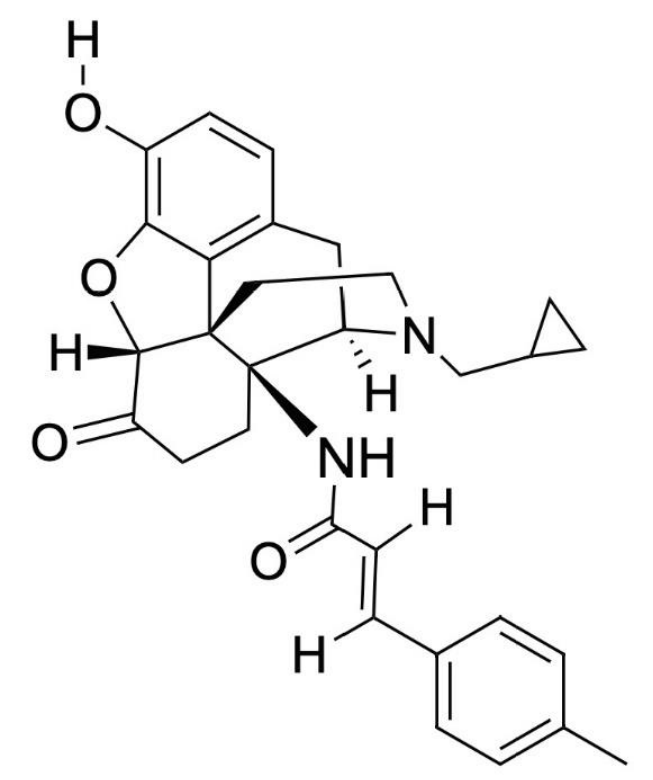

Figure 1. Methocinnamox chemical structure. Molecular Formula: C30H32N2O4, PubChem CID: 46877713, IUPAC name: (E)-N-(4R,4aS,7aR,12bR)-3(cyclopropylmethyl)-9-hydroxy-7-oxo-2,4,5,6,7a,13hexahydro-1H-4,12-methanobenzofuro3,2-eisoquinolin4a-yl-3-(4-methylphenyl)prop-2-enamide (compound/methocinnamox) $)^{112}$.
Naltrexone and naloxone injections become ineffective in less than a single day with durations of action lasting 1-2 hours. ${ }^{85,86}$ A single injection of MCAM has a duration of action of thirteen days, reaching peak concentration 15-45 minutes after injection with a half-life of roughly 70 minutes. ${ }^{19,24,98}$ MCAM's exact mechanism of action is currently unknown, but the effectiveness at very low plasma levels suggests the pharmacodynamic properties play a significant role in its long-lasting effects rather than pharmacokinetic factors. ${ }^{19}$ The evidence for pseudo-irreversible binding includes its nonreversible, insurmountable, and time-dependent antagonism of $\mathrm{mu}$ agonist-inhibition of cAMP production. ${ }^{99}$ A recent study using human embryonic kidney (HEK) cells expressing human opioid receptors showed that in addition to pseudoirreversible orthosteric antagonism of MORs, directly blocking binding, MCAM also utilizes allosteric antagonism at an unknown site at a lower affinity, which alters ligand affinity and/or intrinsic efficacy of MOR agonists. ${ }^{99}$ As for MCAM's mechanistic interaction with DORs and KORs, the behavior was consistent in the opioid receptor expressing HEK cells, and in vivo, with simple competitive antagonism..$^{99}$

Repeated administration of MCAM every twelve days in rodents remained effective for over two-months without altering the duration of opioid withdrawal with no major ADRs and no decrease in effectiveness, suggesting positive potential for longterm OUD treatment. ${ }^{19,21,96}$ Naltrexone, naloxone, and MCAM are effective for acute reversal and prevention of respiratory depression and other overdose symptoms due to their effects on opioid receptors, but only MCAM prevents renarcotization in the hours and days following emergency intervention. ${ }^{19,48,96,98,100}$ Naltrexone and naloxone bind competitively, meaning higher amounts of an agonist will overcome their intended effects requiring a higher dose of either therapy to reverse initial and subsequent overdoses post-antagonistinjection. ${ }^{98}$ MCAM binds non-competitively, making it insurmountable and therefore more 
effective at blocking effects of opioids in the shortand long-term. ${ }^{19,24,99,100}$ Additionally, MCAM is naloxone-insensitive with no notable drug interactions meaning there is a possibility that the two drugs could be administered concurrently for immediate rescue and prevent subsequent renarcotization. ${ }^{99} \mathrm{With}$ over-the-counter availability of naloxone, overdose related deaths have decreased but subsequent renarcotization and therefore consequent overdoses leading to death remains an issue. ${ }^{55,99}$ If a shorter acting formulation of MCAM was combined with naloxone, renarcotization risk could significantly decrease and potentially further reduce opioid overdose related deaths without inducing withdrawal.

MCAM can act as a preventative therapy for opioid misuse, indicating possible use at discharge from treatment facilities following a detoxification period, as well as use during ongoing therapeutic intervention negating the need for, and misuse of, buprenorphine and methadone. ${ }^{22,24,48,100}$ Its prolonged dosing interval is hypothesized to relatively prevent patient noncompliance that is seen with extended-release naltrexone for outpatient treatment, including eliminating the possibility of an individual removing an implant. ${ }^{22,24}$ In cases where effects lasting roughly five days or less are needed, such as preventing renarcotization in the hours and few days following an overdose but not for long term treatment of OUD, intravenous administration of MCAM would be preferable. ${ }^{96,98}$ There is discussion of creating an oral pill form of MCAM, an extended release form, and faster acting intranasal and intramuscular formulations, but further study of the drug is needed before these will be developed. . $^{1,22,98}$ MCAM also blocks the physiological and behavioral effects of MOR agonists such as unfavorable impacts of sensitivity to mechanical stimulation, gastrointestinal motility, appetite, and memory and other cognition, suggesting the adverse effect profile is encouraging. ${ }^{21,22,25,97,101}$ However, it is important to recognize that no testing has been conducted in humans. ${ }^{92}$ It is currently unknown if long-term blockade of the mu receptor would attenuate endorphin and enkephalin signaling sufficiently to reduce mood. Given the wide-spread impact of opioid overdoses, novel strategies are desperately needed.

\section{Conclusion}

The increased prevalence of OUD cases and opioid related deaths are an ongoing public health crisis in the US. While opioid antagonists, naltrexone and naloxone, are essential drugs used to treat OUD and reverse the effects of an overdose, respectively, they have risks that pose considerable limitations to their efficacy. These risks include withdrawal, poor patient compliance, short durations of action, lack of concurrent antinociceptive treatment, ability to surmount opioid receptor blockade, and potentially dangerous drug-drug interactions, especially for those with comorbid addictions. ${ }^{12,19,22,85,91}$ Opioid agonists methadone and buprenorphine present their own limitations in OUD treatment such as dependence, restricted availability, poor patient retention, patient noncompliance, drug-drug interactions necessary detoxification and potential withdrawal. ${ }^{15,81-83}$ Buprenorphine is a Schedule III and methadone is Schedule II substance in the US, so misuse and diversion of these substances is an ongoing challenge. ${ }^{16,17}$ The demand for novel therapeutics to decrease the misuse and overuse of opioid drugs and resulting overdoses provides an opportunity for MCAM to make a positive impact. By retaining the safety benefits of naltrexone and naloxone and providing a longer DOA with a novel mechanism, MCAM is a promising pharmacological addition. Using non-MOR agonists such as the KOR agonist spiradoline concomitantly with MCAM also presents a potential intervention method allowing for antinociceptive effects during the withdrawal process and OUD treatment. $48,98,102,103$ The preclinical phase of MCAM drug development began in 2005 with testing in mice, rats, and non-human primates. 21,48,95-101 Researchers aim to begin phase I clinical trials by 2022.92 MCAM has the potential to 
transform the future of OUD treatment, thereby reducing the healthcare and societal burden caused by the opioid epidemic, ${ }^{1,2}$ and improving the lives of millions.

Acknowledgements: The authors extend gratitude to Iris Johnston in Library Services at Geisinger Commonwealth School of Medicine for her assistance and support during the research process.

\section{References}

(1) Mann, B. More than a Million Americans Have Died from Overdoses during the Opioid Epidemic. NPR. December 30, 2021.

(2) Coussens, N. P.; Sittampalam, G. S.; Jonson, S. G.; Hall, M. D.; Gorby, H. E.; Tamiz, A. P.; McManus, O. B.; Felder, C. C.; Rasmussen, K. The Opioid Crisis and the Future of Addiction and Pain Therapeutics. J Pharmacol Exp Ther 2019, 371 (2), 396-408. https://doi.org/10.1124/jpet.119.259408.

(3) Bechara, A.; Berridge, K. C.; Bickel, W. K.; Morón, J. A.; Williams, S. B.; Stein, J. S. A Neurobehavioral Approach to Addiction: Implications for the Opioid Epidemic and the Psychology of Addiction. Psychol Sci Public Interest 2019, 20 (2), 96-127. https://doi.org/10.1177/1529100619860513.

(4) Torralva, R.; Janowsky, A. Noradrenergic Mechanisms in Fentanyl-Mediated Rapid Death Explain Failure of Naloxone in the Opioid Crisis. J Pharmacol Exp Ther 2019, 371 (2), 453-475. https://doi.org/10.1124/jpet.119.258566.

(5) Hoffman, K. A.; Ponce Terashima, J.; McCarty, D. Opioid Use Disorder and Treatment: Challenges and Opportunities. BMC Health Serv Res 2019, 19 (1), 884. https://doi.org/10.1186/s12913-019-4751-4.

(6) Raehal, K. M.; Bohn, L. M. Mu Opioid Receptor Regulation and Opiate Responsiveness. AAPS J 2005, 7 (3), E587E591. https://doi.org/10.1208/aapsj070360.

(7) Pan, Z. Z. Mu-Opposing Actions of the Kappa-Opioid Receptor. Trends Pharmacol Sci
1998, 19 (3), 94-98.

https://doi.org/10.1016/s0165-6147(98)01169-9.

(8) Tofighi, B.; Williams, A. R.; Chemi, C.; SuhailSindhu, S.; Dickson, V.; Lee, J. D. Patient

Barriers and Facilitators to Medications for Opioid Use Disorder in Primary Care: An inDepth Qualitative Survey on Buprenorphine and Extended-Release Naltrexone. Subst Use Misuse 2019, 54 (14), 2409-2419.

https://doi.org/10.1080/10826084.2019.1653324.

(9) Skolnick, P. On the Front Lines of the Opioid Epidemic: Rescue by Naloxone. Eur J

Pharmacol 2018, 835, 147-153. https://doi.org/10.1016/j.ejphar.2018.08.004.

(10) Ryan, S. A.; Dunne, R. B. Pharmacokinetic Properties of Intranasal and Injectable Formulations of Naloxone for Community Use: A Systematic Review. Pain Manag 2018, 8 (3), 231-245. https://doi.org/10.2217/pmt-20170060 .

(11) Hammerslag, L. R.; Hofford, R. S.; Kang, Q.; Kryscio, R. J.; Beckmann, J. S.; Bardo, M. T. Changes in Fentanyl Demand Following Naltrexone, Morphine, and Buprenorphine in Male Rats. Drug Alcohol Depend 2020, 207, 107804.

https://doi.org/10.1016/j.drugalcdep.2019.1078 04.

(12) Moss, R. B.; Carlo, D. J. Higher Doses of Naloxone Are Needed in the Synthetic Opioid Era. Subst Abuse Treat Prev Policy 2019, 14 (1), 6. https://doi.org/10.1186/s13011-019-0195-4.

(13) Virgin, Y. DEA: “Lazarus parties” or "Narcan parties" are real I KABB https://foxsanantonio.com/news/yamiinvestigates/dea-lazarus-parties-or-narcanparties-are-real (accessed 2022 -01 -23).

(14) Minozzi, S.; Amato, L.; Vecchi, S.; Davoli, M.; Kirchmayer, U.; Verster, A. Oral Naltrexone Maintenance Treatment for Opioid Dependence. Cochrane Database Syst Rev 2011, No. 4, CD001333. https://doi.org/10.1002/14651858.CD001333.pu b4. 
(15) Mattick, R. P.; Kimber, J.; Breen, C.; Davoli, M. Buprenorphine Maintenance versus Placebo or Methadone Maintenance for Opioid Dependence. Cochrane Database Syst Rev 2004, No. 3, CD002207. https://doi.org/10.1002/14651858.CD002207.pu b2.

(16) Hswen, Y.; Zhang, A.; Brownstein, J. S. Leveraging Black-Market Street Buprenorphine Pricing to Increase Capacity to Treat Opioid Addiction, 2010-2018. Prev Med 2020, 137, 106105. https://doi.org/10.1016/j.ypmed.2020.106105.

(17) Simpson, K. J.; Moran, M. T.; McCall, K. L.; Herbert, J.; Foster, M. L.; Simoyan, O. M.; Shah, D. T.; Desrosiers, C.; Nichols, S. D.; Piper, B. J. Increasing Heroin, Cocaine, and Buprenorphine Arrests Reported to the Maine Diversion Alert Program. Forensic Sci Int 2019, 303, 109924. https://doi.org/10.1016/j.forsciint.2019.109924.

(18) Sordo, L.; Barrio, G.; Bravo, M. J.; Indave, B. I.; Degenhardt, L.; Wiessing, L.; Ferri, M.; PastorBarriuso, R. Mortality Risk during and after Opioid Substitution Treatment: Systematic Review and Meta-Analysis of Cohort Studies. BMJ 2017, 357, j1550. https://doi.org/10.1136/bmj.j1550.

(19) Maguire, D. R.; Gerak, L. R.; Sanchez, J. J.; Javors, M. A.; Disney, A.; Husbands, S. M.; France, C. P. Effects of Acute and Repeated Treatment with Methocinnamox, a Mu Opioid Receptor Antagonist, on Fentanyl SelfAdministration in Rhesus Monkeys. Neuropsychopharmacology 2020, 45 (12), 19861993. https://doi.org/10.1038/s41386-020-06988.

(20) Broadbear, J. H.; Sumpter, T. L.; Burke, T. F.; Husbands, S. M.; Lewis, J. W.; Woods, J. H.; Traynor, J. R. Methocinnamox Is a Potent, Long-Lasting, and Selective Antagonist of Morphine-Mediated Antinociception in the Mouse: Comparison with Clocinnamox, Beta-
Funaltrexamine, and Beta-Chlornaltrexamine. J Pharmacol Exp Ther 2000, 294 (3), 933-940.

(21) Gerak, L. R.; Gould, G. G.; Daws, L. C.; France, C. P. Methocinnamox Produces Sustained Antagonism of the Antinociceptive Effects of Morphine and Persistent Decreases in [3H]DAMGO Binding to $\mu$ Opioid Receptors in Rat Cortex. FASEB J 2020, 34 (S1), $1-1$.

https://doi.org/10.1096/fasebj.2020.34.s1.05397.

(22) Maguire, D. R.; Gerak, L. R.; Woods, J. H.; Husbands, S. M.; Disney, A.; France, C. P. Long-Lasting Effects of Methocinnamox on Opioid Self-Administration in Rhesus Monkeys. J Pharmacol Exp Ther 2019, 368 (1), 88-99. https://doi.org/10.1124/jpet.118.252353.

(23) Zamora, J. C.; Kotipalli, V.; Jennings, E. M.; Disney, A.; Husbands, S.; Winger, G.; Clarke, W. P.; Woods, J. H.; Berg, K. A.

Methocinnamox (MCAM) Is a Selective, Long Acting Antagonist at Mu Opioid Receptors In Vitro. FASEB J 2019, 33 (S1), 498.8-498.8. https://doi.org/10.1096/fasebj.2019.33.1_supple ment.498.8.

(24) Townsend, E. A. The Lasting Impact of Methocinnamox on Opioid SelfAdministration. Neuropsychopharmacology 2020, 45 (12), 1963-1964. https://doi.org/10.1038/s41386-020-0717-9.

(25) Minervini, V.; France, C. Long-Term Antagonism of $\mathrm{Mu}$ Opioid Receptors by Methocinnamox (MCAM) without Adverse Effects on Memory. FASEB J 2020, 34 (S1), 1-1. https://doi.org/10.1096/fasebj.2020.34.s1.00750.

(26) Lyden, J.; Binswanger, I. A. The United States Opioid Epidemic. Semin Perinatol 2019, 43 (3), 123-131. https://doi.org/10.1053/j.semperi.2019.01.001.

(27) Courtwright, D. T. Preventing and Treating Narcotic Addiction - A Century of Federal Drug Control. New Eng J Med 2015, 373 (22), 2095-2097. https://doi.org/10.1056/NEJMp1508818. 
(28) Levy, N.; Sturgess, J.; Mills, P. “Pain as the Fifth Vital Sign" and Dependence on the "Numerical Pain Scale" Is Being Abandoned in the US: Why? Br J Anaesth 2018, 120 (3), 435-438. https://doi.org/10.1016/j.bja.2017.11.098.

(29) Van Zee, A. The Promotion and Marketing of OxyContin: Commercial Triumph, Public Health Tragedy. Am J Public Health 2009, 99 (2), 221-227. https://doi.org/10.2105/AJPH.2007.131714.

(30) Jones, M. R.; Viswanath, O.; Peck, J.; Kaye, A. D.; Gill, J. S.; Simopoulos, T. T. A Brief History of the Opioid Epidemic and Strategies for Pain Medicine. Pain Ther 2018, 7 (1), 13-21. https://doi.org/10.1007/s40122-018-0097-6.

(31) Singh, V. M.; Browne, T.; Montgomery, J. The Emerging Role of Toxic Adulterants in Street Drugs in the US Illicit Opioid Crisis. Public Health Rep 2020, 135 (1), 6-10. https://doi.org/10.1177/0033354919887741.

(32) Seth, P.; Scholl, L.; Rudd, R. A.; Bacon, S. Overdose Deaths Involving Opioids, Cocaine, and Psychostimulants - United States, 20152016. MMWR Morb Mortal Wkly Rep 2018, 67 (12), 349-358. https://doi.org/10.15585/mmwr.mm6712a1.

(33) Stoicea, N.; Costa, A.; Periel, L.; Uribe, A.; Weaver, T.; Bergese, S. D. Current Perspectives on the Opioid Crisis in the US Healthcare System: A Comprehensive Literature Review. Medicine (Baltimore) 2019, 98 (20), e15425.

https://doi.org/10.1097/MD.0000000000015425.

(34) Hagemeier, N. E. Introduction to the Opioid Epidemic: The Economic Burden on the Healthcare System and Impact on Quality of Life. Am J Manag Care 2018, 24 (10 Suppl), S200-S206.

(35) Pashmineh Azar, A. R.; Cruz-Mullane, A.; Podd, J. C.; Lam, W. S.; Kaleem, S. H.; Lockard, L. B.; Mandel, M. R.; Chung, D. Y.; Simoyan, O. M.; Davis, C. S.; Nichols, S. D.; McCall, K. L.; Piper, B. J. Rise and Regional
Disparities in Buprenorphine Utilization in the United States. Pharmacoepidemiol Drug Saf 2020, 29 (6), 708-715. https://doi.org/10.1002/pds.4984.

(36) Furst, J. A.; Mynarski, N. J.; McCall, K. L.; Piper, B. J. Pronounced Regional Disparities in United States Methadone Distribution. Ann Pharmacother 2021, 10600280211028262. https://doi.org/10.1177/10600280211028262.

(37) Frank, R. G.; Fry, C. E. The Impact of Expanded Medicaid Eligibility on Access to Naloxone. Addiction 2019, 114 (9), 1567-1574. https://doi.org/10.1111/add.14634.

(38) CDC. Drug Overdose Deaths in the U.S. Top 100,000 Annually https://www.cdc.gov/nchs/pressroom/nchs_pr ess_releases/2021/20211117.htm (accessed 2022 $-01-24)$.

(39) CDC. Understanding the Epidemic I CDC's Response to the Opioid Overdose Epidemic I CDC

https://www.cdc.gov/opioids/basics/epidemic. html (accessed 2022 -01 -23).

(40) Han, Y.; Yan, W.; Zheng, Y.; Khan, M. Z.; Yuan, K.; Lu, L. The Rising Crisis of Illicit Fentanyl Use, Overdose, and Potential Therapeutic Strategies. Transl Psychiatry 2019, 9 (1), 1-9. https://doi.org/10.1038/s41398-0190625-0.

(41) McIver, J. S. Seeking Solutions to the Opioid Crisis. P T 2017, 42 (7), 478.

(42) Saloner, B.; McGinty, E. E.; Beletsky, L.; Bluthenthal, R.; Beyrer, C.; Botticelli, M.; Sherman, S. G. A Public Health Strategy for the Opioid Crisis. Public Health Rep 2018, 133 (1 Suppl), 24S-34S. https://doi.org/10.1177/0033354918793627.

(43) Caton, L.; Cheng, H.; Garneau, H. C.; Fisher, T.; Harris-Mills, B.; Hurley, B.; Newman, S.; McGovern, M. P. COVID-19 Adaptations in the Care of Patients with Opioid Use Disorder: A Survey of California Primary Care Clinics. J Gen Intern Med 2021, 1-8. https://doi.org/10.1007/s11606-020-06436-3. 
(44) Drake, J.; Charles, C.; Bourgeois, J. W.; Daniel, E. S.; Kwende, M. Exploring the Impact of the Opioid Epidemic in Black and Hispanic Communities in the United States. Drug Sci. Policy Law 2020, 0, 1-11. https://doi.org/10.1177/2050324520940428.

(45) Kolodny, A.; Courtwright, D. T.; Hwang, C. S.; Kreiner, P.; Eadie, J. L.; Clark, T. W.; Alexander, G. C. The Prescription Opioid and Heroin Crisis: A Public Health Approach to an Epidemic of Addiction. Annu Rev Public Health 2015, 36, 559-574.

https://doi.org/10.1146/annurev-publhealth031914-122957.

(46) France, C. P.; Ahern, G. P.; Averick, S.; Disney, A.; Enright, H. A.; Esmaeli-Azad, B.; Federico, A.; Gerak, L. R.; Husbands, S. M.; Kolber, B.; Lau, E. Y.; Lao, V.; Maguire, D. R.; Malfatti, M. A.; Martinez, G.; Mayer, B. P.; Pravetoni, M.; Sahibzada, N.; Skolnick, P.; Snyder, E. Y.; Tomycz, N.; Valdez, C. A.; Zapf, J. Countermeasures for Preventing and Treating Opioid Overdose. Clin Pharmacol Ther 2020. https://doi.org/10.1002/cpt.2098.

(47) Volkow, N. D.; Blanco, C. The Changing Opioid Crisis: Development, Challenges and Opportunities. Mol Psychiatry 2021, 26 (1), 218-233. https://doi.org/10.1038/s41380-0200661-4.

(48) Gerak, L. R.; Latham, E. A.; Woods, J. H.; Disney, A.; Husbands, S. M.; France, C. P. Methocinnamox: Sustained Antagonism of the Antinociceptive Effects of Morphine and Not Spiradoline in Rats. FASEB J 2019, 33 (S1), 498.10-498.10.

https://doi.org/10.1096/fasebj.2019.33.1_supple ment.498.10.

(49) Jennings, E. M.; Disney, A.; Husbands, S.; Winger, G.; Berg, K. A.; Clarke, W. P.; Woods, J. H. Methocinnamox (MCAM) Is an Effective Long-Term Antagonist of Peripheral Mu, but Not Kappa or Delta Opioid Receptors In Vivo. FASEB J 2019, 33 (S1), 498.9-498.9. https://doi.org/10.1096/fasebj.2019.33.1_supple ment.498.9.

(50) Manglik, A.; Lin, H.; Aryal, D. K.; McCorvy, J. D.; Dengler, D.; Corder, G.; Levit, A.; Kling, R. C.; Bernat, V.; Hübner, H.; Huang, X.-P.; Sassano, M. F.; Giguère, P. M.; Löber, S.; Da Duan, null; Scherrer, G.; Kobilka, B. K.; Gmeiner, P.; Roth, B. L.; Shoichet, B. K. Structure-Based Discovery of Opioid Analgesics with Reduced Side Effects. Nature 2016, 537 (7619), 185-190. https://doi.org/10.1038/nature19112.

(51) Mafi, A.; Kim, S.-K.; Goddard, W. A. Mechanism of $\beta$-Arrestin Recruitment by the $\mu$-Opioid G Protein-Coupled Receptor. Proc Natl Acad Sci U S A 2020, 117 (28), 1634616355.

https://doi.org/10.1073/pnas.1918264117.

(52) Gibula-Tarlowska, E.; Kotlinska, J. H.

Crosstalk between Opioid and Anti-Opioid Systems: An Overview and Its Possible Therapeutic Significance. Biomolecules 2020, 10 (10), 1376. https://doi.org/10.3390/biom10101376.

(53) Al-Hasani, R.; Bruchas, M. R. Molecular Mechanisms of Opioid Receptor-Dependent Signaling and Behavior. Anesthesiology 2011, 115 (6), 1363-1381.

https://doi.org/10.1097/ALN.0b013e318238bba 6.

(54) Corder, G.; Castro, D. C.; Bruchas, M. R.; Scherrer, G. Endogenous and Exogenous Opioids in Pain. Annu Rev Neurosci 2018, 41, 453-473. https://doi.org/10.1146/annurevneuro-080317-061522.

(55) Mondal, D.; Kolev, V.; Warshel, A. Exploring the Activation Pathway and Gi-Coupling Specificity of the $\mu$-Opioid Receptor. PNAS 2020, 117 (42), 26218-26225. https://doi.org/10.1073/pnas.2013364117.

(56) Smrcka, A. V. G Protein B $\gamma$ Subunits: Central Mediators of G Protein-Coupled Receptor Signaling. Cell Mol Life Sci 2008, 65 (14), 2191- 
2214. https://doi.org/10.1007/s00018-008-80065.

(57) Shenoy, S. S.; Lui, F. Biochemistry, Endogenous Opioids. In StatPearls; StatPearls Publishing: Treasure Island (FL), 2020.

(58) National Academies of Sciences, E.; Division, H. and M.; Policy, B. on H. S.; Disorder, C. on M.-A. T. for O. U.; Mancher, M.; Leshner, A. I. The Effectiveness of Medication-Based Treatment for Opioid Use Disorder; National Academies Press (US), 2019.

(59) Lipiński, P. F. J.; Kosson, P.; Matalińska, J.; Roszkowski, P.; Czarnocki, Z.; Jarończyk, M.; Misicka, A.; Dobrowolski, J. C.; Sadlej, J. Fentanyl Family at the Mu-Opioid Receptor: Uniform Assessment of Binding and Computational Analysis. Molecules 2019, 24 (4), 1-30. https://doi.org/10.3390/molecules24040740.

(60) Navratilova, E.; Ji, G.; Phelps, C.; Qu, C.; Hein, M.; Yakhnitsa, V.; Neugebauer, V.; Porreca, F. Kappa Opioid Signaling in the Central Nucleus of the Amygdala Promotes Disinhibition and Aversiveness of Chronic Neuropathic Pain. Pain 2019, 160 (4), 824-832. https://doi.org/10.1097/j.pain.000000000000145 8.

(61) Zhou, W.; Li, Y.; Meng, X.; Liu, A.; Mao, Y.; Zhu, X.; Meng, Q.; Jin, Y.; Zhang, Z.; Tao, W. Switching of Delta Opioid Receptor Subtypes in Central Amygdala Microcircuits Is Associated with Anxiety States in Pain. J Biol Chem 2021, 296, 100277.

https://doi.org/10.1016/j.jbc.2021.100277.

(62) Al-Eitan, L. N.; Rababa'h, D. M.; Alghamdi, M. A. Genetic Susceptibility of Opioid Receptor Genes Polymorphism to Drug Addiction: A Candidate-Gene Association Study. BMC Psychiatry 2021, 21 (1), 5. https://doi.org/10.1186/s12888-020-03006-z.

(63) Liu, S. S.; Pickens, S.; Burma, N. E.; IbarraLecue, I.; Yang, H.; Xue, L.; Cook, C.; Hakimian, J. K.; Severino, A. L.; Lueptow, L.; Komarek, K.; Taylor, A. M. W.; Olmstead, M.
C.; Carroll, F. I.; Bass, C. E.; Andrews, A. M.; Walwyn, W.; Trang, T.; Evans, C. J.; Leslie, F. M.; Cahill, C. M. Kappa Opioid Receptors Drive a Tonic Aversive Component of Chronic Pain. J Neurosci 2019, 39 (21), 41624178.

https://doi.org/10.1523/JNEUROSCI.027419.2019 .

(64) Massaly, N.; Copits, B. A.; Wilson-Poe, A. R.; Hipólito, L.; Markovic, T.; Yoon, H. J.; Liu, S.; Walicki, M. C.; Bhatti, D. L.; Sirohi, S.; Klaas, A.; Walker, B. M.; Neve, R.; Cahill, C. M.; Shoghi, K. I.; Gereau, R. W.; McCall, J. G.; AlHasani, R.; Bruchas, M. R.; Morón, J. A. PainInduced Negative Affect Is Mediated via Recruitment of The Nucleus Accumbens Kappa Opioid System. Neuron 2019, 102 (3), 564-573.

https://doi.org/10.1016/j.neuron.2019.02.029.

(65) Rosenblum, A.; Marsch, L. A.; Joseph, H.;

Portenoy, R. K. Opioids and the Treatment of Chronic Pain: Controversies, Current Status, and Future Directions. Exp Clin Psychopharmacol 2008, 16 (5), 405-416. https://doi.org/10.1037/a0013628.

(66) Mercadante, S.; Arcuri, E.; Santoni, A. OpioidInduced Tolerance and Hyperalgesia. CNS Drugs 2019, 33 (10), 943-955.

https://doi.org/10.1007/s40263-019-00660-0.

(67) Kosten, T. R.; George, T. P. The Neurobiology of Opioid Dependence: Implications for Treatment. Sci Pract Perspect 2002, 1 (1), 13-20.

(68) Srivastava, A.; Kahan, M.; Nader, M. Primary Care Management of Opioid Use Disorders: Abstinence, Methadone, or BuprenorphineNaloxone? Can Fam Physician 2017, 63 (3), 200205.

(69) Heo, Y.-A.; Scott, L. J.

Buprenorphine/Naloxone (Zubsolv®): A Review in Opioid Dependence. CNS Drugs 2018, 32 (9), 875-882. https://doi.org/10.1007/s40263-018-0560-2.

(70) Sullivan, M. A.; Bisaga, A.; Pavlicova, M.; Carpenter, K. M.; Choi, C. J.; Mishlen, K.; 
Levin, F. R.; Mariani, J. J.; Nunes, E. V. A Randomized Trial Comparing ExtendedRelease Injectable Suspension and Oral Naltrexone, Both Combined With Behavioral Therapy, for the Treatment of Opioid Use Disorder. Am J Psychiatry 2019, 176 (2), 129137.

https://doi.org/10.1176/appi.ajp.2018.17070732.

(71) Chen, K. Y.; Chen, L.; Mao, J. BuprenorphineNaloxone Therapy in Pain Management. Anesthesiology 2014, 120 (5), 1262-1274. https://doi.org/10.1097/ALN.000000000000017 0.

(72) Kapur, B. M.; Hutson, J. R.; Chibber, T.; Luk, A.; Selby, P. Methadone: A Review of DrugDrug and Pathophysiological Interactions. Crit Rev Clin Lab Sci 2011, 48 (4), 171-195. https://doi.org/10.3109/10408363.2011.620601.

(73) Jarvis, B. P.; Holtyn, A. F.; Subramaniam, S.; Tompkins, D. A.; Oga, E. A.; Bigelow, G. E.; Silverman, K. Extended-Release Injectable Naltrexone for Opioid Use Disorder: A Systematic Review. Addiction 2018, 113 (7), 1188-1209. https://doi.org/10.1111/add.14180.

(74) Morgan, J. R.; Schackman, B. R.; Leff, J. A.; Linas, B. P.; Walley, A. Y. Injectable Naltrexone, Oral Naltrexone, and Buprenorphine Utilization and Discontinuation among Individuals Treated for Opioid Use Disorder in a United States Commercially Insured Population. J Subst Abuse Treat 2018, 85, 90-96. https://doi.org/10.1016/j.jsat.2017.07.001.

(75) Sudakin, D. Naltrexone: Not Just for Opioids Anymore. J Med Toxicol 2016, 12 (1), 71-75. https://doi.org/10.1007/s13181-015-0512-x.

(76) David, S. P.; Lancaster, T.; Stead, L. F.; Evins, A. E.; Prochaska, J. J. Opioid Antagonists for Smoking Cessation. Cochrane Database Syst Rev 2013, 6 (6), CD003086. https://doi.org/10.1002/14651858.CD003086.pu b3.

(77) Bostwick, J. M.; Bucci, J. A. Internet Sex Addiction Treated with Naltrexone. Mayo Clin
Proc 2008, 83 (2), 226-230.

https://doi.org/10.4065/83.2.226.

(78) Garayar Cantero, M.; Canseco Martín, M.; Aguado García, Á.; Ruiz-Sánchez, D.; Valtueña, J.; Manchado López, P. Use of LowDose Naltrexone in the Treatment of Severe Hailey-Hailey Disease: One Case Report. Dermatol Ther 2019, 32 (3), e12892. https://doi.org/10.1111/dth.12892.

(79) Larochelle, M. R.; Bernson, D.; Land, T.; Stopka, T. J.; Wang, N.; Xuan, Z.; Bagley, S. M.; Liebschutz, J. M.; Walley, A. Y. Medication for Opioid Use Disorder After Nonfatal Opioid Overdose and Association With Mortality: A Cohort Study. Ann Intern Med 2018, 169 (3), 137-145. https://doi.org/10.7326/M17-3107.

(80) Ferrari, A.; Coccia, C. P. R.; Bertolini, A.; Sternieri, E. Methadone--Metabolism, Pharmacokinetics and Interactions. Pharmacol Res 2004, 50 (6), 551-559. https://doi.org/10.1016/j.phrs.2004.05.002.

(81) Whelan, P. J.; Remski, K. Buprenorphine vs Methadone Treatment: A Review of Evidence in Both Developed and Developing Worlds. J Neurosci Rural Pract 2012, 3 (1), 45-50. https://doi.org/10.4103/0976-3147.91934.

(82) Welsh, C.; Valadez-Meltzer, A. Buprenorphine. Psychiatry (Edgmont) 2005, 2 (12), 29-39.

(83) Anderson, I. B.; Kearney, T. E. Use of Methadone. West J Med 2000, 172 (1), 43-46.

(84) Cruz, S. L.; Villarreal, J. E.; Volkow, N. D. Further Evidence That Naloxone Acts as an Inverse Opiate Agonist: Implications for Drug Dependence and Withdrawal. Life Sci 1996, 58 (26), 381-389. https://doi.org/10.1016/00243205(96)00250-0.

(85) Rzasa Lynn, R.; Galinkin, J. Naloxone Dosage for Opioid Reversal: Current Evidence and Clinical Implications. Ther Adv Drug Saf 2018, 9 (1), 63-88. https://doi.org/10.1177/2042098617744161. 
(86) Schumacher, M. A.; Basbaum, A. I.; Naidu, R. K. Opioid Agonists \& Antagonists. In Basic E Clinical Pharmacology; Katzung, B. G., Ed.; McGraw-Hill Education: New York, NY, 2017.

(87) Gracely, R. H.; Dubner, R.; Wolskee, P. J.;

Deeter, W. R. Placebo and Naloxone Can Alter Post-Surgical Pain by Separate Mechanisms.

Nature 1983, 306 (5940), 264-265.

https://doi.org/10.1038/306264a0.

(88) Eippert, F.; Bingel, U.; Schoell, E. D.;

Yacubian, J.; Klinger, R.; Lorenz, J.; Büchel, C.

Activation of the Opioidergic Descending

Pain Control System Underlies Placebo

Analgesia. Neuron 2009, 63 (4), 533-543.

https://doi.org/10.1016/j.neuron.2009.07.014.

(89) Wachman, E. M.; Saia, K.; Miller, M.; Valle, E.; Shrestha, H.; Carter, G.; Werler, M.; Jones, H.

Naltrexone Treatment for Pregnant Women With Opioid Use Disorder Compared With Matched Buprenorphine Control Subjects.

Clin Ther 2019, 41 (9), 1681-1689.

https://doi.org/10.1016/j.clinthera.2019.07.003.

(90) Tran, T. H.; Griffin, B. L.; Stone, R. H.; Vest, K. M.; Todd, T. J. Methadone, Buprenorphine, and Naltrexone for the Treatment of Opioid Use Disorder in Pregnant Women.

Pharmacotherapy 2017, 37 (7), 824-839.

https://doi.org/10.1002/phar.1958.

(91) Krupitsky, E.; Nunes, E. V.; Ling, W.; Illeperuma, A.; Gastfriend, D. R.; Silverman, B. L. Injectable Extended-Release Naltrexone for Opioid Dependence: A Double-Blind, Placebo-Controlled, Multicentre Randomised Trial. Lancet 2011, 377 (9776), 1506-1513. https://doi.org/10.1016/S0140-6736(11)60358-9.

(92) Mertens, J. YOUR HEALTH: Something better than Naloxone I wqad.com https://www.wqad.com/article/news/health/y our-health/your-health-mcam/526-cda2622a69a3-4962-885a-a2185e9507d6.

(93) National Institute On Drug Abuse. A Novel Opioid Receptor Antagonist For Treating Abuse and Overdose https://taggs.hhs.gov/Detail/AwardDetail?arg
_AwardNum=R01DA048417\&arg_ProgOffice Code $=114$.

(94) National Institute of Health. Funded Projects https://www.heal.nih.gov/funding/awarded.

(95) Sansom, W. Long-lasting treatment drug could slow the opioid crisis https://news.uthscsa.edu/long-lastingtreatment-drug-could-slow-the-opioid-crisis/ (accessed 2021 -02 -15).

(96) Jimenez, V. M.; Castaneda, G.; France, C. P. Methocinnamox (MCAM) Reverses and Prevents Fentanyl-Induced Ventilatory Depression in Rats. J Pharmacol Exp Ther 2021. https://doi.org/10.1124/jpet.120.000387.

(97) Minervini, V.; Disney, A.; Husbands, S. M.; France, C. P. Methocinnamox (MCAM) Antagonizes the Behavioral Suppressant Effects of Morphine without Impairing Delayed Matching-to-Sample Accuracy in Rhesus Monkeys. Psychopharmacology (Berl) 2020, 237 (10), 3057-3065. https://doi.org/10.1007/s00213-020-05592-y.

(98) Gerak, L. R.; Maguire, D. R.; Woods, J. H.; Husbands, S. M.; Disney, A.; France, C. P. Reversal and Prevention of the RespiratoryDepressant Effects of Heroin by the Novel $\mu$ Opioid Receptor Antagonist Methocinnamox in Rhesus Monkeys. J Pharmacol Exp Ther 2019, 368 (2), 229-236. https://doi.org/10.1124/jpet.118.253286.

(99) Zamora, J. C.; Smith, H. R.; Jennings, E. M.; Chavera, T. S.; Kotipalli, V.; Jay, A.; Husbands, S. M.; Disney, A.; Berg, K. A.; Clarke, W. P. Long-term Antagonism and Allosteric Regulation of Mu Opioid Receptors by the Novel Ligand, Methocinnamox.

Pharmacol Res Perspect 2021, 9 (6), e00887. https://doi.org/10.1002/prp2.887.

(100) Peckham, E. M.; Barkley, L. M.; Divin, M. F.; Cicero, T. J.; Traynor, J. R. Comparison of the Antinociceptive Effect of Acute Morphine in Female and Male Sprague-Dawley Rats Using the Long-Lasting Mu-Antagonist Methocinnamox. Brain Res 2005, 1058 (1-2), 
137-147.

https://doi.org/10.1016/j.brainres.2005.07.060.

(101) Gerak, L. R.; Minervini, V.; Latham, E.;

Ghodrati, S.; Lillis, K. V.; Wooden, J.; Disney,

A.; Husbands, S. M.; France, C. P.

Methocinnamox Produces Long-Lasting

Antagonism of the Behavioral Effects of $\mu$ -

Opioid Receptor Agonists but Not Prolonged Precipitated Withdrawal in Rats. J Pharmacol

Exp Ther 2019, 371 (2), 507-516.

https://doi.org/10.1124/jpet.119.260331.

(102) Vonvoigtlander, P. F.; Lewis, R. A. Analgesic and Mechanistic Evaluation of Spiradoline, a Potent Kappa Opioid. J Pharmacol Exp Ther 1988, 246 (1), 259-262.

(103) Wadenberg, M.-L. G. A Review of the Properties of Spiradoline: A Potent and Selective Kappa-Opioid Receptor Agonist. CNS Drug Rev 2003, 9 (2), 187-198.

https://doi.org/10.1111/j.1527-

3458.2003.tb00248.x.

(104) Naloxone

https://go.drugbank.com/drugs/DB01183

(accessed 2022 -01 -26).

(105) Naloxone Monograph for Professionals https://www.drugs.com/monograph/naloxone .html (accessed 2022 -01 -26).

(106) Naltrexone https://go.drugbank.com/drugs/DB00704 (accessed 2022 -01-26).

(107) Naltrexone Monograph for Professionals https://www.drugs.com/monograph/naltrexo ne.html (accessed 2022 -01 -26).

(108) Methadone

https:/go.drugbank.com/drugs/DB00333 (accessed 2022 -01-26).

(109) Methadone Monograph for Professionals https://www.drugs.com/monograph/methado ne.html (accessed 2022 -01 -26).

(110) Buprenorphine https://go.drugbank.com/drugs/DB00921 (accessed 2022 -01-26).
(111) Buprenorphine Monograph for Professionals https://www.drugs.com/monograph/buprenor phine.html (accessed 2022 -01 -26).

(112) PubChem. Compound Summary Methocinnamox https://pubchem.ncbi.nlm.nih.gov/compound/ 46877713 (accessed 2021 -05 -15). 